\title{
Assessing the decoupling of economic growth from environmental impacts in industrial regions of the Russian Federation: an impact decoupling approach
}

\author{
Anna Pepelyaeva*, and Aleksandra Krutova \\ Perm National Research Polytechnic University, 29, Komsomolsky prospect, Perm, 614000, Russia
}

\begin{abstract}
The article analyzes the dynamics of the economic activity level in Russian industrial regions and its impact on the main environmental elements (water, air and soil) by calculating the decoupling coefficient. In the study a hierarchical cluster analysis was carried out, resulted in the formation of seven regional clusters, five of which had a significant share of the industrial sector in the gross value-added structure. Decoupling coefficients were calculated for 64 constituent entities of the Russian Federation belonging to different types of industrial clusters. The ecological and economic balance assessment of industrial regions growth showed the decoupling effect presence for most of them. The movement towards environmentally sustainable growth is more evident in the regions of the industrially diversified cluster. The analysis of three decoupling coefficients showed that in the vast majority of industrial regions the growth rates of pollutant emissions into the atmosphere and the growth rates of polluted wastewater discharges into surface water change at a lower rate than per capita GRP, which indicates a "green trend" in the region's economic activity. However, the decoupling coefficient, showing the dynamics ratio of production and consumption waste and GRP per capita, has negative value in $37.5 \%$ of regions. The most problematic one in terms of this indicator was the Trade and manufacturing cluster, including 21 constituent entities of the Russian Federation. According to the authors, it may be related to the trade sector of these regions.
\end{abstract}

\section{Introduction}

Dramatic climate change, declining biodiversity, and land degradation are just a few of the challenges humanity facing in an effort to improve its well-being. Extensive economic growth due to increased consumption and pressure on the environment has already led to irreversible consequences. The situation calls for fundamental changes in production and consumption patterns on the part of humanity. The post-industrial stage of economic development implies not only its structural and sectoral restructuring, a change in the technological basis of production, or an increase in the number of hightech industries, but also its greening. Economic growth at the national or regional level, including the growth of industrial production, should be considered together with national or regional environmental safety, which is the main condition for the long-term socio-economic development of the territory.

In 2011, the United Nations Environment Program (UNEP) called for a decoupling of economic growth and environmental impact (UNEP, 2011). Decoupling occurs when the growth rate of economic activity is higher than that of resource use or environmental impact (relative decoupling), or there is an increase in economic activity while decreasing resource use or reducing the environmental impact associated with this economic activity (absolute decoupling) [1].
The term "decoupling" in environmental economics was proposed by the OECD in 2000 in "Indicators to Measure Decoupling of Environmental Pressure from Economic Growth Organization for Economic Cooperation and Development" [2] and means "the process of sustainable, long-term, predictable and controlled trends decoupling in economic growth, consumption of natural resources and environmental pollution at all stages of the product life cycle, without redistributing environmental risks in time and space" [3, p. 4].

The decoupling effect can be achieved through a conscious transition to a circular economy, which involves the transformation of linear material flows into cyclical ones through a combination of intelligent infrastructure and product design, standardization, reuse, recycling and recovery [4].

The emergence of the decoupling effect remains one of the most important growth trends in the region's industrial sector. The issues of using decoupling for the study of environmental and economic problems in Russia at the macroeconomic level are considered in the studies of Bobylev S.N., Zakharov V.M., Mikhailova E.G., Prokopyev M.G. and others [5-7].

The assessment of ecological and economic progress at the regional level through the calculation of the decoupling index or decoupling factor was carried out in the studies of such Russian scientists as Akulov A.O., Anikina I.D., Anikin A.A., Bashirova A.A., Gorbunova

\footnotetext{
* Corresponding author: alexkrutova@ yandex.ru
} 
V.A. S., Zabelina I.A., Kalashnikova I.V., Kirillov S.N., Kozhevnikov S.A., Korobitsin B.A., Lebedeva M.A., Pakina A.A., Samarina V.P., Trushkova E.A., Shkiperova G.T., Filippova K.V., Fesenko R.S., Fomina V.F., Fomin A.V., Chumakov V.N., Yashalova N.N. and others [8-19].

As a part of the methodological approach for assessing decoupling of growth trends in the global, national or regional economy and the corresponding ecosystem, resource decoupling and impact decoupling are assessed. Resource decoupling reflects the efficiency of using natural resources at all stages of the production process, impact decoupling shows the use of waste-free technologies and the efficiency of treatment facilities [20]. The presence of resource decoupling and impact decoupling indicates a movement towards circular economy.

In this study, the authors assessed the presence of impact decoupling in regional industrial-type clusters in the Russian Federation.

\section{Materials and methods}

Research hypothesis: the sectoral structure of the Russian regions influences decoupling indicators.

The aim of the study is to identify and analyze the effect of decoupling in the ecological and economic activities of Russian industrial regions.

The methodology proposed by the authors for assessing the impact decoupling in the constituent entities of the Russian Federation of industrial type includes several stages.

At the first stage, the Russian regions were grouped according to the structure of gross value added (GVA) based on the method of hierarchical cluster analysis.

Clustering was carried out on the sectoral structure of GVA basis according to OKVED 2 established in the Russian regions in 2017. Seventeen types of economic activity were identified: sections $\mathrm{P}, \mathrm{O}$, and $\mathrm{Q}$ were combined, $\mathrm{T}$ and $\mathrm{U}$ were excluded from the analysis, since they do not consider the enterprises economic activities in the region.

As a result, 7 clusters of the Russian regions were identified: "Industrial-diversified", "Trademanufacturing", "Logistic", "Agrarian-touristic", "Manufacturing", "Mining-social" and "Mining" [21, p. 95-108].

For further analysis, 5 industrial-type clusters were taken (regions included in the logistics and agrariantouristic clusters were excluded from further research).

At the second stage, indicators are proposed to assess the decoupling effect through the Decoupling Index or the Decoupling Factor.

In this study, three decoupling factors will be calculated according to general formula 1 .

$$
D=1-\frac{E P_{t} / D F_{t}}{E P_{0} / D F_{0}}
$$

where DF0, DFt (Driving Force) is an indicator of economic growth in the base and current periods; EP0, EPt (Environment Pressure) are indicators of the negative impact on the environment in the base and current periods.

As an indicator of economic growth (DF), the study will use GRP per capita (rubles/person). As an indicator of the negative impact on the regional ecosystem for the calculation of D1, the EP1 indicator is proposed as the emissions of pollutants into the atmosphere per capita (tons/person); for calculating D2 the EP2 indicator is used as the discharge of polluted wastewater into surface water per capita (m3/person); for calculating D3 the indicator EP3 is used as production and consumption waste per capita (tons/person).

The choice of indicators is conditioned by the following requirements: objectivity; importance of the indicator; quantifiability; relevance, i.e. the indicators structure and composition should correspond to the structure of the "Environment Pressure" category and be sufficiently indicative for regional assessment; indicators reliability and availability, the possibility of comparison in dynamics taking into account regional specifics.

In addition, the choice of the proposed indicators of negative impact on the regional ecosystem is due to the fact that the anthropogenic pressure on the environment is carried out in all its subsystems: air, land and water. The use of per capita indicators in the study allows for more objective interregional comparison.

At the third stage, the data collection and processing for the regions of the selected clusters, calculation and assessment of decoupling coefficients (D1, D2, D3) were carried out.

Since the indicator of "production and consumption waste" in the regional context has been published by the Federal State Statistics Service once every two years since 2011, and the data on GRP for 2019 have not yet been published by Rosstat, the study period was limited by the time period of 2011-2017. In addition, the Republic of Crimea and the city of Sevastopol were excluded from further analysis, as they were not part of the Russian Federation at the beginning of the analyzed period.

\section{Results and discussion}

Table 1 shows the calculated decoupling coefficients for five clusters of the Russian industrial regions.

The positive value of the decoupling coefficients $\left(D_{1}\right.$, $\mathrm{D}_{2}, \mathrm{D}_{3}$ ) indicates the presence of the decoupling effect, the multidirectional dynamics of the regional economy growth and pressure on the territory ecosystem, the excess of economic growth rates over the environmental pressure growth rates, and negative value exceeds the environmental burden growth rates over economic growth. That could be interpreted as obtaining a lower economic result on the amount of resources spent, accompanied by deterioration of the environmental situation. 
Table 1. Impact decoupling coefficients $(D i)$ in Russian industrial-type regions *

\begin{tabular}{|c|c|c|c|}
\hline Regional grouping by clusters & $\mathbf{D}_{1}$ & $\mathbf{D}_{2}$ & $\mathbf{D}_{3}$ \\
\hline \multicolumn{4}{|c|}{ Industrial-diversified cluster (10 regions) } \\
\hline Belgorod region & 0,31 & 0,37 & 0,30 \\
\hline Kursk region & 0,33 & 0,84 & 0,33 \\
\hline Republic of Karelia & 0,24 & 0,22 & 0,24 \\
\hline Murmansk region & 0,45 & 0,43 & 0,42 \\
\hline Republic of Tatarstan & 0,33 & 0,61 & $-0,56$ \\
\hline Udmurt Republic & 0,19 & 0,59 & 0,15 \\
\hline Samara region & 0,42 & 0,37 & 0,46 \\
\hline Perm territory & 0,25 & 0,44 & 0,25 \\
\hline Krasnoyarsk region & 0,90 & 0,58 & 0,25 \\
\hline The Republic of Khakassia & 0,85 & 0,63 & $-1,83$ \\
\hline \multicolumn{4}{|c|}{ Trade and manufacturing cluster (21 regions) } \\
\hline Bryansk region & 0,39 & 0,58 & $-0,14$ \\
\hline Oryol region & 0,23 & 0,41 & $-0,38$ \\
\hline Stavropol region & 0,39 & 0,46 & $-0,80$ \\
\hline Pskov region & 0,11 & 0,45 & $-5,73$ \\
\hline Voronezh region & 0,41 & 0,52 & $-0,43$ \\
\hline Tambov region & 0,34 & $-1,82$ & $-2,40$ \\
\hline Kaliningrad region & 0,48 & 0,30 & $-0,64$ \\
\hline Rostov region & 0,34 & 0,48 & 0,47 \\
\hline Republic of Adygea & 0,19 & 0,53 & 0,11 \\
\hline Penza region & 0,39 & 0,50 & 0,23 \\
\hline Altai region & 0,76 & 0,06 & $-2,02$ \\
\hline Novosibirsk region & 0,16 & 0,48 & $-42,51$ \\
\hline Ivanovo region & 0,39 & 0,52 & 0,43 \\
\hline Kostroma region & 0,22 & 0,46 & 0,47 \\
\hline Moscow region & 0,38 & 0,51 & $-5,30$ \\
\hline Smolensk region & 0,36 & 0,46 & $-0,79$ \\
\hline Tver region & 0,27 & 0,45 & $-0,93$ \\
\hline Moscow city & 0,32 & 0,41 & $-0,22$ \\
\hline Saint Petersburg & 0,31 & 0,54 & $-0,18$ \\
\hline Kurgan region & 0,38 & 0,46 & $-0,02$ \\
\hline Saratov region & 0,32 & 0,65 & $-0,01$ \\
\hline \multicolumn{4}{|c|}{ Mining and social cluster (9 regions) } \\
\hline Komi Republic & 0,49 & $-0,54$ & 0,27 \\
\hline Kemerovo region & $-0,16$ & 0,53 & 0,06 \\
\hline Tomsk region & 0,34 & 0,42 & 0,53 \\
\hline Irkutsk region & 0,85 & 0,52 & 0,23 \\
\hline Chukotka Autonomous Okrug & 0,39 & 0,63 & 0,16 \\
\hline Republic of Sakha (Yakutia) & $-2,60$ & 0,71 & $-0,31$ \\
\hline Magadan region & 0,45 & 0,74 & $-1,85$ \\
\hline Astrakhan region & 0,66 & 0,72 & 0,69 \\
\hline Orenburg region & 0,42 & 0,46 & 0,21 \\
\hline
\end{tabular}

\begin{tabular}{|c|c|c|c|}
\hline \multicolumn{4}{|c|}{ Manufacturing cluster (21 regions) } \\
\hline Vladimir region & 0,36 & 0,47 & 0,56 \\
\hline Nizhny Novgorod region & 0,42 & 0,51 & 0,43 \\
\hline Sverdlovsk region & 0,45 & 0,54 & 0,42 \\
\hline Yaroslavl region & 0,47 & 0,54 & $-0,03$ \\
\hline Republic of Bashkortostan & 0,24 & 0,46 & 0,66 \\
\hline Leningrad region & 0,32 & 0,27 & $-0,58$ \\
\hline Ryazan region & 0,47 & 0,47 & 0,27 \\
\hline Kirov region & 0,38 & 0,69 & 0,46 \\
\hline Chuvash Republic & 0,18 & $-1,27$ & 0,12 \\
\hline Ulyanovsk region & 0,34 & 0,41 & 0,29 \\
\hline Arkhangelsk region & 0,55 & 0,48 & $-1,05$ \\
\hline Volgograd region & 0,31 & 0,61 & 0,06 \\
\hline Mari El Republic & 0,35 & 0,54 & 0,35 \\
\hline The Republic of Mordovia & 0,25 & 0,65 & 0,28 \\
\hline Kaluga region & 0,26 & 0,54 & 0,28 \\
\hline Tula region & 0,52 & 0,57 & $-0,62$ \\
\hline Lipetsk region & 0,43 & 0,47 & 0,56 \\
\hline Vologda region & 0,40 & 0,36 & 0,28 \\
\hline Novgorod region & 0,29 & 0,81 & 0,42 \\
\hline Chelyabinsk region & 0,53 & 0,53 & 0,28 \\
\hline Omsk region & $-1,77$ & 0,47 & 0,44 \\
\hline \multicolumn{4}{|c|}{ Mining cluster (3 regions) } \\
\hline Sakhalin Region & 0,15 & 0,44 & 0,33 \\
\hline $\begin{array}{c}\text { Tyumen region (including } \\
\text { Khanty-Mansi Autonomous } \\
\text { Okrug and Yamalo-Nenets } \\
\text { Autonomous Okrug) }\end{array}$ & 0,55 & 0,35 & 1,00 \\
\hline Nenets Autonomous Okrug & 0,59 & 0,02 & $-39,64$ \\
\hline
\end{tabular}

According to Table 1, a number of conclusions can be drawn.

For all the analyzed clusters, the coefficient $D_{1}$, reflecting the result of comparing the growth rates of pollutant emissions into the atmosphere from stationary sources per capita with the growth rates of GRP per capita, has a predominantly positive value. This may indicate the regions movement towards the introduction of circular economy principles in matters related to air pollution.

It should be noted that the total emissions of air pollutants in 2017 compared to 2010 changed insignificantly, the decrease was less than $1 \%$. Also, insignificant changes took place in the sectoral structure of air emissions, where the emissions from manufacturing enterprises dominate (Figure 1). 


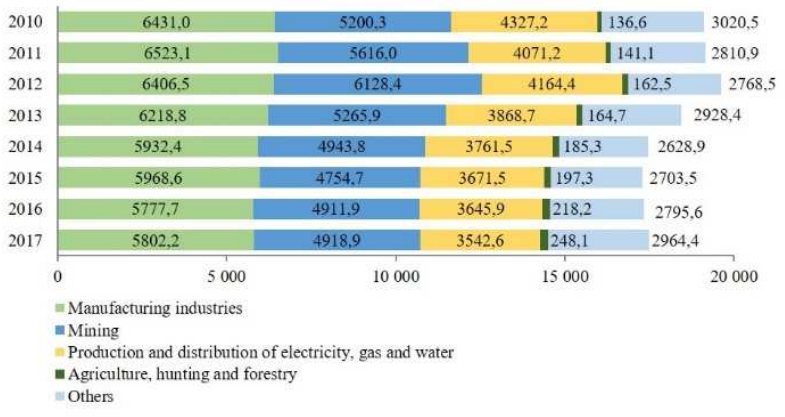

Figure 1. Distribution of emissions (thousand tons) from stationary sources by type of economic activity, 2010-2017 in the Russian Federation [24]

According to the report "On the state and protection of the environment of the Russian Federation in 2017" [24], a number of measures were implemented in 2017 to reduce emissions of pollutants into the atmosphere. The total amount of financing used for their implementation amounted to 59.8 bln rubles. Among the main production activities noted in the report, it is worth mentioning the improvement of technological processes, an increase in the efficiency of existing treatment facilities, the commissioning of new treatment plants, sources of pollution, etc.

Thus, we can state the effectiveness of the implemented actions from the circular economy perspective, the excess of the growth rate of economic activity over the growth rate of pressure on the environment.

Coefficient $\mathrm{D}_{2}$ shows the growth rate ratio of polluted wastewater discharges into surface water per capita with the growth rate of GRP per capita. As in the case with the $\mathrm{D}_{1}$ coefficient, positive values prevail in all analyzed clusters.

It is due to the fact that for the period of 2010-2017 the volume of wastewater discharge into surface natural water bodies of the Russian Federation decreased by $13.4 \%$ and amounted to $42,575.74 \mathrm{mln}^{3}$ in 2017 [24]. This trend may be associated with an increase in fixed capital investments during this period aimed at putting into operation wastewater treatment facilities and water recycling systems by $43 \%$ [24].

It is worth paying attention to the volume distribution of water protection capacity in 2017 between federal districts (Figure 2). The largest volume is in the Siberian Federal District. For regions of the Siberian Federal District, the $\mathrm{D}_{2}$ coefficients have positive values, while in the regions with relatively smaller capacities for water resources protection, there are also negative values of the $\mathrm{D}_{2}$ coefficient.

A decrease in the volume of wastewater discharge, along with the obtained positive values of the decoupling coefficient $\mathrm{D}_{2}$, also indicates the effectiveness of the implemented measures, a decrease in pressure on the environment per unit of economic effect.

The coefficient $\mathrm{D}_{3}$ values, reflecting the ratio of the production and consumption waste rates per capita with the growth rates of GRP, differ significantly from the previous indicators values. It should be noted that the regional coefficients values depend on their belonging to a particular cluster (Figure 3).

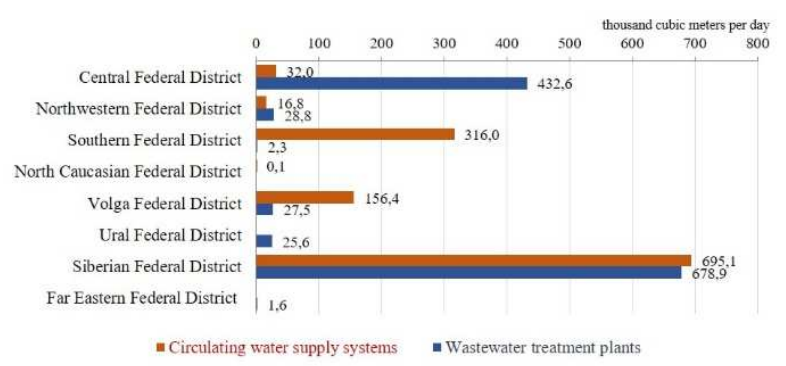

Figure 2. Distribution of capacities commissioning volume for the protection of water resources in 2017 by federal district in the Russian Federation [24]

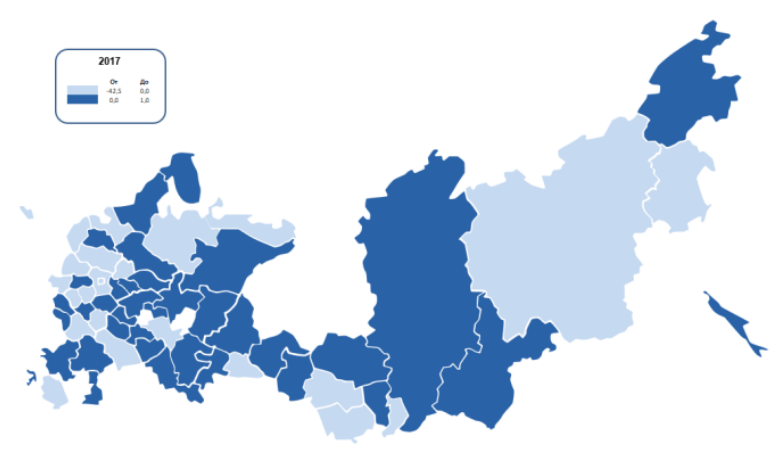

Figure 3. Distribution of industrial regions of the Russian Federation by decoupling coefficient $\mathrm{D}_{3}$

For an industrially diversified cluster including 10 regions, with prevailing share of manufacturing industries, a high share of the mining industry, the average level of the trade and social sphere, positive values of decoupling coefficients were obtained, except the Republic of Tatarstan and the Republic of Khakassia. Also, this cluster is characterized by a relatively small range of the decoupling coefficient values variation, the difference between the maximum and minimum values within this cluster is 2.29 . On the one hand, it shows the homogeneity of the regions included into the cluster from the standpoint of the environmental impact dynamics per unit of economic result, and the improvement of the cluster regions in the field of circular economy on the other hand.

Similar conclusions can be drawn regarding the Manufacturing cluster and Mining-social cluster. Manufacturing cluster including 21 constituent entities of the Russian Federation is characterized by a predominant share of the manufacturing industry, an average level of trade and social sphere, the absence of mining industry. The mining-social cluster includes 9 regions, in the GVA structure of which the mining industry share prevails, it has an average share of the social sphere and an insignificant share of other types of activity. Positive values of the coefficient $\mathrm{D}_{3}$ and a relatively small range of variation of these indicators also prevail here.

The "Trade and manufacturing cluster" including 21 regions is characterized by a high share of trade and manufacturing industry, and the absence of the mining industry. The cluster is the most interesting one for 
further research. The predominance of the decoupling coefficient negative values indicates that the growth rates of production and consumption waste significantly exceed the growth rates of GRP.

Since in three clusters of regions - "Industrialdiversified", "Manufacturing" and "Trade and manufacturing", manufacturing industries occupy a significant share (the average share amounted to $23 \%$, $30.6 \%$ and $18.2 \%$ respectively) in the sectoral structure of economic activity, and a negative coefficient $\mathrm{D}_{3}$ is mainly observed in the regions of the Trade and manufacturing cluster, it can be assumed that with improvement of technological basis in the manufacturing sector of the Russian regions, the indicator of waste may grow due to the trade sector.

The best available technology approach in the implementation of environmental and industrial policies is the measure to prevent environmental pollution and good feasibility management of sector-specific environmental impacts. It is actively introduced at industrial enterprises with the most negative impact on the environment. Since January 2015, the requirements for environmental regulation have been established according to Federal law No. 219-FL [25] based on technology standards that should not exceed the technological indicators of the best available technologies. However, considering the application areas of available technologies, it is revealed that trade is not included in the list of BAT application areas, which may indicate the lack of requirements for processes, technologies, services and criteria for achieving environmental objectives.

\section{Conclusion}

The practical significance of this study is the impact decoupling analyses of the Russian regions, taking into account the sectoral structure, which can be used to develop a strategy for regional sustainable growth.

As a result of the study, for 64 regions of the Russian Federation included in industrial clusters of different types, three decoupling indicators were calculated for the period of 2011-2017: the ratio of changes in the volume of emissions into the atmosphere, the discharge of polluted wastewater into surface water, the volume of waste generation per GRP unit.

According to the first two indicators $\left(D_{1}, D_{2}\right)$, positive values are observed in most regions of industrial clusters, which indicates the movement of these regions towards circular economy and ensuring regional environmental safety.

However, according to the indicator assessing the dynamics of production and consumption waste per capita and per capita GRP, in $37.5 \%$ of regions there is a negative value of decoupling factor, and the most problematic for this indicator was the "Trade and manufacturing cluster", in which $88 \%$ of regions received negative values. According to the authors, it may relate to the trade sector of these regions.

At the next stage of the study, the resource decoupling of the selected regions will be assessed, and more detailed analysis of the most problematic and successful regions of each cluster will be carried out in order to identify the factors of the largest (negative or positive) impact of economic practices and instruments of regional industrial policy on regional ecosystems to improve them.

\section{References}

1. E. Sanye-Mengual, M. Secchi, S. Corrado, A. Beylot, S. Sala, Journal of Cleaner Production, 236 (2019)

2. Indicators to Measure Decoupling of Environmental Pressure from Economic Growth Organization for Economic Co-operation and Development, Retrieved from: http://www.oecd.org/officialdocuments/publicdisp laydocumentpdf $/$ ?doclanguage $=$ en $\&$ cote $=s g / s d(20$ 02)1/final

3. V.P. Samarina, National interests: priorities and security, 2 (2015)

4. Ellen MacArthur Foundation official website Retrieved from: https://www.ellenmacarthurfoundation.org/

5. S.N. Bobylev, V.M. Zakharov, On the way to sustainable development of Russia: bulletin, 60 (2012)

6. E.G. Mikhailova, Economic and Social Changes: Facts, Trends, Forecast, 11 (2018)

7. M.G. Prokopyev, Market economy problems, 2 (2020)

8. A.O. Akulov, Economic and social changes: facts, trends, forecast, 4 (2013)

9. I.D. Anikina, A.A. Anikin, Regionalnaya ekonomika. Yug Rossii, 7 (2019)

10. A.A. Bashirova, Management of economic systems: electronic scientific journal, 10 (2016).

11. I.A. Zabelina, Economic and Social Changes: Facts, Trends, Forecasts, 12 (2019)

12. M.A. Lebedeva, Actual problems of modern economy, 6 (2018)

13. S.N. Kirillov, A.A. Pakina, N.I. Tulskaya, Science Journal of VolSU. Global Economic System, 19 (2017)

14. S.A. Kozhevnikov, M.A. Lebedeva, Problems of Territory's Development, 4 (2019)

15. B.A. Korobitsyn, Biosphere compatibility: people, region, technologies, 21 (2018)

16. V.N. Chumakov, R.S. Fesenko, V.S. Gorbunova, Bulletin of Education and Science Development of the Russian Academy of Natural Sciences, 22 (2018)

17. G.T. Shkiperova, Economic analysis: theory and practice, 43 (2014)

18. V.F. Fomina, A.V. Fomin, North and the market: the formation of the economic order, 1 (2018)

19. N.N. Yashalova, Regional economy: theory and practice, 39 (2014)

20. Y. Wu et al., Journal of Cleaner Production, 190 (2018)

21. V. Karpushkina et al. Problems of economic security: challenges and experience in the digital 
economy (Publishing Center of SUSU, Chelyabinsk, 2019)

22. Rosstat Environmental protection in Russia 2018: Statistical collection Retrieved from: https://gks.ru/bgd/regl/b18 54/Main.htm

23. Regions of Russia. Socio-economic indicators. 2020: Statistical collection (Moscow, 2020)

24. Rosstat State report "On the state and protection of the environment of the Russian Federation in 2017" Retrieved from: https://gosdokladecology.ru/2017

25. Federal Law N 219-FZ "On Amending the Federal Law" On Environmental Protection "and Certain Legislative Acts of the Russian Federation". Retrieved from: http://www.consultant.ru/document/cons_doc_LA W_165823/ 